Management Dynamics

Vol. 23, No. 1: 37-54, 2020

Shanker Dev Campus

Doi: https://doi.org/10.3126/md.v23i1.35542

\title{
Consumer Purchase Intention towards Organic Foods
}

\begin{abstract}
This research tries to measure consumer purchase intention toward organic foods. The descriptive and causal research design was used. Primary cross-section data were collected by administering structured questionnaires. Two-hundred responses were collected. The convenience sampling method was used. The PLS-SEM tool was used to test the psychometric and econometric dimensions of the proposed model. This research confirmed that environmental concern, trust, and availability were the important predictor for motivating organic food purchase intention. Health concern and awareness were not supported for organic food purchase intention. Marketers have to make their organic food easily available in the markets with a view of health and environmental consciousness to generate trust.
\end{abstract}

Keywords: Consumer purchase intention, organic foods, PLS-SEM

\section{Introduction}

Consumer behavior is related to how consumers select, evaluates, and purchase the products, followed by after-sales activities. There are increasing trends that consumers are seeking to purchase organic foods. Consumers' knowledge and willingness to lead a healthier lifestyle and maintain the fragile environment is rising. Marketers should measure consumer interest in health and the environment as a marketing opportunity to reach concerned customers with organically grown goods (Bharathi et al., 2014). Organizations accept organic consumerism in their marketing strategies (Ottman, 1992; Salzman, 1991). Organic products are products based on the ecological aspect, not for economic aspects (Dahama, 1997). Organic fertilizers are used for farming products, and biological pest control is used for farming organic products (Dahama, 1997). It is the purchase of products least harmful to human or environmental health (Lea \& Worsley, 2005). Buying organic food refers to important factors such as supportive of health, good to the environment, recyclable, and responsive to ecological concerns (Mostafa, 2007).

*Dr. Shrestha is Associate Professor at Tribhuvan University, Faculty of Management, Shanker Dev Campus. Email:drsajeeb@gmail.com 
Organic food marketing is growing slowly in Nepal. Consumers are increasingly showing concern towards organic foods, and producers are producing products organically. People want to live a healthy lifestyle. People want to know how pesticides are used in crops. Adhikari (2014) depicted that 17 percent of people are aware of Nepal's organic products. Currently, there are around 800 registered organic food producers in Nepal (Dhungana, 2014). These organizations have been producing chemical-free organic foods and promoting them.

\section{Literature review and theoretical framework Theoretical support}

The theory of reasoned action (Ajzen \& Fishbein, 1975, 1980) justifies the purchase decision factors. This theory is applied in marketing to predict consumer behavior and make strategies to intervene. Consumer attitudes explain human actions (Ajzen \& Fishbein, 1980). Consumers are rational consumers and collect and use the information to test and purchase the products (Peter \& Olson, 2002). People measure their actions' decision to involve or not be involved in the behavior (Ajzen \& Fishbein, 1980).

Social identity theory suggests that people define themselves based on personal and social aspects (Tajfel, 1981, 1982). Social identity theory tests different alliances and relations between personal and social identities (Tajfel, 1982). Personal identity depicts a person's distinct characteristics, including personality traits and abilities. The social aspect (i.e., social identification) refers to the perception of belonging to a human group (Ashforth \& Mael, 1989). The social identity theory will attempt to specify and forecast the conditions in which individuals think of themselves as individuals or as members of groups. The Theory also discusses the effect of collective culture and individual identity.

\section{Consumer purchase intention}

Consumer purchase intention is likely to purchase the products, so it is important for consumer buying behavior (Chen, 2010). Ajzen's (1991) model of the theory of planned behavior gives insights to purchase intention of organic products defining consumers' buying behavior.

\section{Health concern}

The health concern is about people's concern towards his/her own health. So, people buy fresh and certified products to protect their health (Sangkumchalianga \& Huang, 2012; Vermeir \& Verbeke, 2004)). The health concern is almost a major issue for purchasing organic foods products (Lea \& Worsley 2005; Magistris \& Garcia, 2008; Roitner-Schobesberger et al., 2008; Tsakiridou et al., 2008). Yiridoe et al. (2005) confirmed that organic food purchase is the outcome of one major determinant: human health.

Researchers confirmed that consumer attitudes towards health issues are an important dimension for organic food purchases (Durham \& Andrade, 2005; Krystallis \& Chryssochoidis, 2005; Padel \& Foster, 2005). Suh et al. (2012) found that people have beliefs about organic food are good for health. 
H1: Health concern influence organic food purchase intention.

\section{Environmental concern}

Environmental concern is prominent for consumers to purchase organic foods (Yiridoe et al., 2005). The environmental issue is burning issues, and the government and people are acting like a watchdog in products harming the environment. People are concerned about whether organic products protect the environment or harm the environment (Numraktrakul et al., 2011). The consumer considers environmental issues before buying products (Zelezny \& Schultz, 2000). It's also the organic producers' strategy to use it as unique selling propositions (USP) to sell their products. Consumers may boycott the manufacturer's products that are not environment friendly (Chen, 2010).

Researchers found an important connection between organic purchasing and environmental consciousness (Numraktrakul et al., 2011). Consumer sensitivity to environmental issues plays a major role in improving consumers' attitudes in their everyday lives (Kim \& Han, 2010). Research from Vermeir and Verbeke (2006) and Chen (2007) shows that people who are more environmentally conscious and actively interested in the organic movement consume more organic foods.

\section{H2: Environmental concern influence organic food purchase intention.}

\section{Trust}

Chen and Chang (2012) depict trust as a measure of overall willingness to rely on an object, individual, or organization based on three things - credibility, benevolence, and ability. Trust is important for long term organic business association. In the sustainable growth of the business, trust also plays a central role in consumer loyalty and word-of-mouth referrals. Rizwan et al. (2013) found that organic trust is a clear determinant of purchase decisionmaking. Bahr et al. (2004) agree that trust is important in the organic food industry. Trust in organic foods has a significant effect on purchasing organic foods (Chen \& Chang, 2012; Gupta \& Ogden, 2009). Trust is an important element in how individuals make buying decisions in risky food markets.

Buyers are still seeking various ways of mitigating risk associated with foods (Brunel, 2003), such as brands' image (Gurviez \& Korchia, 2002), shop image, and label references. Relevant people or companies would be relied on to make quality decisions (Sirieix et al., 2004).

Trust can be directed towards the company, the logo, but also the interests of producing partners. Studying trust orientations will understand the marketplace of organic goods, distribution networks, and certification agencies. Organic food intake is directly related to consumers' overall confidence in society. Consumers are concerned with organic foods consumers, including their level of confidence in organic certification marks, trust in products' countries of origin, and their level of trust in the ownership networks for organic food (Hamzaoui \& Zahaf, 2008). 
H3: Trust influence organic food purchase intention.

\section{Awareness}

Consumer awareness about organic foods has a greater impact on purchasing organic foods (Azizan \& Suki, 2014). Consumers who have organic knowledge or awareness about sensitivity to human health and environmental and ecological sustainability show more concern about organic food purchasing (Huang \& Teng, 2013). The demand for organic food among consumers is important because it affects consumer perceptions towards organic foods (Briz \& Ward 2009; Gil \& Soler 2006).

The effect of consumer's awareness has a positive impact on their attitude towards organic food (Chryssochoidis, 2000; Padel \& Foster, 2005). Shamsollani et al. (2013) show that as people become more educated, their buying tendencies are heightened. Research has established that ecological awareness affects purchasing organic water saving goods.

Stobbelaar et al. (2007) argue that the more you know about organic food, the more confident you will be in your attitude towards it. Organic product awareness is vital because it helps customers distinguish the characteristics of conventional goods from organic ones, form positive attitudes towards organics, and make buying decisions.

\section{H4: Awareness influence organic food purchase intention.}

\section{Availability}

Availability considerations include areas in which people can hear about and buy the commodity. It covers the distribution network, volume, ranges, location, and stock, and transmitting finished and semi-finished goods to customers. Zhen and Mansori (2012) argue as the user believes that the item is readily accessible.

Consumers would be hesitant to spend money on an item if there is no organic alternative on the shelves for them (Vermeir \& Verbeke, 2004). Availability is the level of ease or difficulty to gain or consume a commodity. Mainieri et al. (1997) reasoned that the consumers' environmental awareness lags behind pro-environmental behavior. Many individuals have a tendency to eat organic goods but do not do so because of the lack of them. There is nothing of evidence that the lack of knowledge makes it more difficult for customers to identify environmentally friendly goods (Brown \& Wahlers, 1998).

The shortage of organic food at the location is one reason customers are hard to keep (Davies et al., 1995). It is necessary to have environmentally friendly companies to get an adequate supply of the product in the market. Consumers should not be confused, so they can be completely inspired to purchase products organically. Kaufmannu et al. (2012) showed that organic goods' availability is essential to enable consumers to increase socially responsible behaviors. 
H5: Availability influence organic food purchase intention.

Thapa (2019) confirmed that consumers are not happy with promoting green products in Nepal. Sharma et al. (2016) found that organic food's unaffordability is one of the major constraints/barriers. Mahato and Kadel (2015) analyzed to gain knowledge about consumers' behavior towards organic food products. Aryal et al. (2009) surveyed the Nepal Permaculture Group and revealed that all respondents would pay a price premium, but the acceptability level differed. Bhatta et al. (2009) found that agrochemicals, higher production costs, and deteriorating ecosystem health have advocated the need to change traditional and external input use agriculture towards safe and sustainable organic production in Nepal. All domestic organic products reach consumers without labeling in Nepal. Most organic consumers will pay eight rupees more for labeled organic vegetables in Nepal (Bhatta et al., 2009).

Organic consumer markets are niche markets, contributing to only $3 \%$ of the overall food purchases (Adhikari, 2014). Urbanization is on the rise. The market is expanding and increasing (Aryal et al., 2009). A situation has been created where all the consumables are available in the hands of the consumers. But even during market expansion, consumer concerns are a major issue. Consumers themselves and companies are also aware of this. Consumers' attention has been diverted to organic products, especially because of health issues that arise from time to time in food and vegetables, such as using non-food items in vegetables and color to make them look fresh. Therefore, this study seeks to determine consumer purchase intention toward organic foods.

There have been done some studies in Nepal (Aryal et al., 2009; Bhatta et al., 2009; Mahato \& Kadel, 2015; Sharma et al., 2016; Thapa, 2019), but this research has been carried out as there is probably no study from the side of advance modeling.

The research questions were as follows,

Does health concern influence organic food purchase intention?

Does environmental concern influence organic food purchase intention?

Does trust influence organic food purchase intention?

Does awareness influence organic food purchase intention?

Does availability influence organic food purchase intention?

The purpose of the study was to examine consumer purchase intention toward organic foods.

A research framework/theoretical framework can guide the study of the variables and establish statistical relationships (Trochim, 2006). Essential assessment of them is made possible by the obvious declaration of the theoretical assumptions (Herek, 1995). The research framework binds the researcher to existing knowledge and allows the researcher to base his theories and choose analysis methods. A research/theoretical context defines the key factors that influence a phenomenon of interest (Herek, 1995). 
Figure1

Research Framework

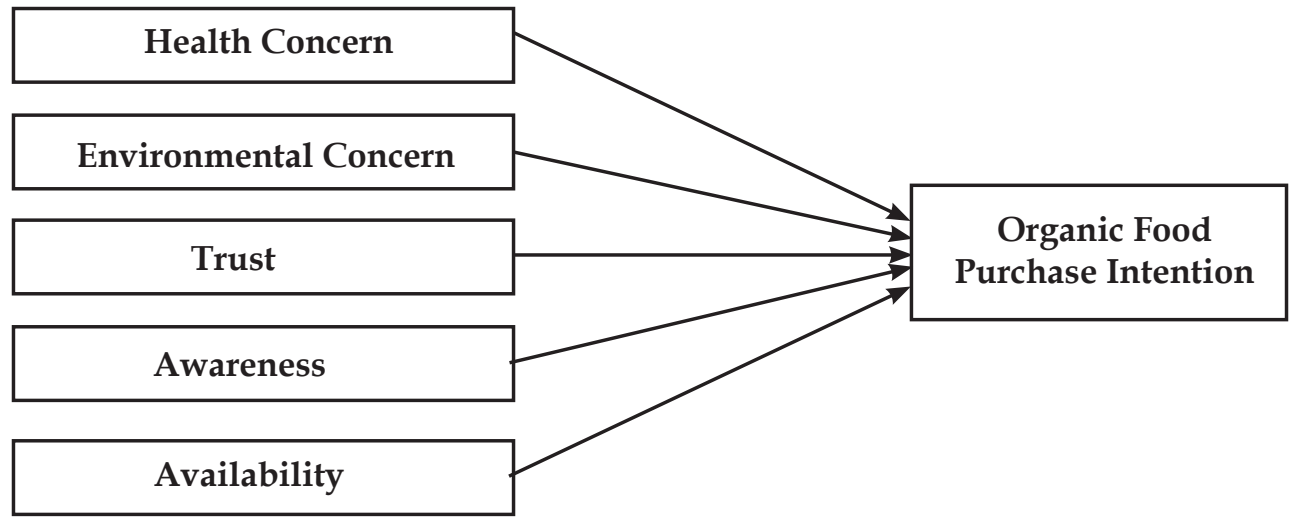

\section{Development of hypothesis}

H1: Health concerns influence organic food purchase intention.

H2: Environmental concern influence on organic food purchase intention.

H3: Trust influence on organic food purchase intention.

H4: Awareness influence on organic food purchase intention.

H5: Availability influence on organic food purchase intention.

This is an important research of the organic food industry for different people. In the study, the results would be beneficial to organic food producers and marketers. They will use this knowledge to devise their marketing plans. When consumers are knowledgeable about organic foods, more and more people will become drawn to them.

\section{Research methodology}

The study design was a descriptive and causal one to achieve objectives (Malhotra \& Birks, 2006). The study of the current literature was meticulous and systematic. Causal research examines the interaction between something (the cause) to the thing (the effect). The variables associated with the econometric model are related to one another, where certain variable values are found to coincide with certain variables of another variable. The primary crosssection data were collected in this study.

The population of the study was people purchasing organic products in Kathmandu City. The study is based in the town of Kathmandu, where the middle and high standard people live. The study's sample frame was the most famous outlets selling organic goods in Kathmandu City and their number of customers. The researcher assumed that these outlets make up over $50 \%$ of the market share in the district. The non-probability sampling method was used for this study. This research has carried out convenience samples, ensuring the public's research findings are relevant (Henry, 1990; Kayaman \& Arasli, 2007; Kobayashi, 2011). For this 
analysis, 200 people were surveyed, which is appropriate for this study (Kline, 2011). This study shows that 100 or more participants are adequate to explain the results while ensuring that enough people get represented (Cavana et al., 2000; Dillman, 2000).

Structured questionnaires were used for data collection. Primary cross-section data were gathered. The survey approach was used for collecting data that are easily distributed and advantage to data consistency (Malhotra \& Birks, 2006).

The instruments were categorized into two parts. The first parts include demographic information, and the second part makes up Likert scale questions. Likert scale questions were anchored by "Strongly Disagree=1" to "Strongly Agree=5".

Respondents who were intercepted at several locations had approved to inquire. Individuals' acts cannot be learned without questioning the people involved in particular (Ghauri \& Gronhaug, 2005). The interviews followed a quick briefing on completing the questionnaire. There were approximately ten minutes required for the respondent to fill the questionnaire. Questionnaires were obtained from different outlet establishments selling organic foods in Kathmandu City.

The proposed model is evaluated using Structural Equation Modeling (SEM). For assessing the validity and reliability of the measures used in the survey, SEM technology is used. Partial Least Square Structural Equation Modeling (PLS-SEM) is used in this research to bootstrap 5000 sub-samples (Hair et al., 2013). Smart PLS 3.0 was used for SEM analysis.

Fifty-five percent of respondents were female, and forty-five percent of respondents were male. Respondents at the age between 20 to 30 years and 30 to 40 years are denoting 42 and 40 percent in total. Sixty-one percent of respondents were bachelor's degree, followed by 24 percent of master's degree respondents. Over 60 percent of employees were accounted for working employees in government and private organizations, and the businessperson was 25 percent. Most of the respondents were an income of Rs. 40,000-Rs. 50,000 of 65 percent, followed by Rs. 30,000-Rs.40,000 was 31 percent.

The limitation of the study was written in this way. This analysis was sampled only in Kathmandu City only. Therefore, the results cannot generalize the entire organic consumption population in Nepal. This research contained only primary data. So, the results have been cross-checked with the secondary sources available, and the results are not very different. There are several other predictors in various circumstances that the research has used a selective variable for confirming the desire of consumers to buy organic food in the Nepalese context. 


\section{Results and discussion}

\section{Measurement model}

The author used internal reliability, convergent validity, and discriminant validity tools to check the model (Hair et al., 2012). Loading each standard indicator is over 0.7, and Dijkstra and Henseler's rho_A of each construct is over 0.70 (Ali et al., 2018; Fornell \& Larcker, 1981; Hair et al., 2017; Hair et al., 2020). Nowadays, the Rho_A value has become more important than Cronbach's Alpha (Hair et al., 2020). During analysis, the average variance extracted (AVE) value should be over 0.5 for each construct, suggesting that convergent validity exists.

Table 1

Evaluation of the outer or measurement model

\begin{tabular}{|c|c|c|c|c|c|c|}
\hline Constructs & $\begin{array}{l}\text { Indicator } \\
\text { items }\end{array}$ & Loadings & $\begin{array}{l}\text { Cronbach } \\
\text { Alpha }\end{array}$ & rho_A & CR & AVE \\
\hline \multirow{3}{*}{ Availability } & AV3 & 0.747 & \multirow{3}{*}{0.762} & \multirow{3}{*}{0.79} & \multirow{3}{*}{0.861} & \multirow{3}{*}{0.675} \\
\hline & AV4 & 0.841 & & & & \\
\hline & AV5 & 0.872 & & & & \\
\hline \multirow{2}{*}{ Awareness } & AW1 & 0.957 & \multirow{2}{*}{0.856} & \multirow{2}{*}{0.942} & \multirow{2}{*}{0.931} & \multirow{2}{*}{0.875} \\
\hline & AW2 & 0.908 & & & & \\
\hline \multirow{4}{*}{$\begin{array}{l}\text { Environmental } \\
\text { Concern }\end{array}$} & EC1 & 0.883 & \multirow{4}{*}{0.893} & \multirow{4}{*}{0.923} & \multirow{4}{*}{0.925} & \multirow{4}{*}{0.755} \\
\hline & EC2 & 0.905 & & & & \\
\hline & $\mathrm{EC} 3$ & 0.828 & & & & \\
\hline & EC4 & 0.858 & & & & \\
\hline \multirow{3}{*}{ Health Concern } & $\mathrm{HC} 3$ & 0.727 & \multirow{3}{*}{0.758} & \multirow{3}{*}{0.794} & \multirow{3}{*}{0.859} & \multirow{3}{*}{0.671} \\
\hline & $\mathrm{HC} 4$ & 0.864 & & & & \\
\hline & HC5 & 0.858 & & & & \\
\hline \multirow{5}{*}{ Purchase Intention } & PI1 & 0.778 & \multirow{5}{*}{0.83} & \multirow{5}{*}{0.841} & \multirow{5}{*}{0.88} & \multirow{5}{*}{0.595} \\
\hline & PI2 & 0.829 & & & & \\
\hline & PI3 & 0.731 & & & & \\
\hline & PI4 & 0.803 & & & & \\
\hline & PI5 & 0.711 & & & & \\
\hline \multirow{3}{*}{ Trust } & TF1 & 0.763 & \multirow{3}{*}{0.734} & \multirow{3}{*}{0.754} & \multirow{3}{*}{0.842} & \multirow{3}{*}{0.641} \\
\hline & TF2 & 0.876 & & & & \\
\hline & TF5 & 0.758 & & & & \\
\hline
\end{tabular}

Table 1 shows all the indicator loading items' value is higher than 0.7 , composite reliability (CR), rho_A, Cronbach's Alpha value is greater than the cutoff value of 0.7 (Ali et al., 2018; Fornell \& Larcker, 1981; Hair et al., 2017, Hair et al., 2020). It is said that convergent validity is obtained.

The value of Table 1 is based on the measurement model explained in Figure 2. Indicator items for each scale and path value, and coefficient of determination $\left(R^{2}\right)$ are shown in Figure 2. 
Figure 2

Measurement model in graph

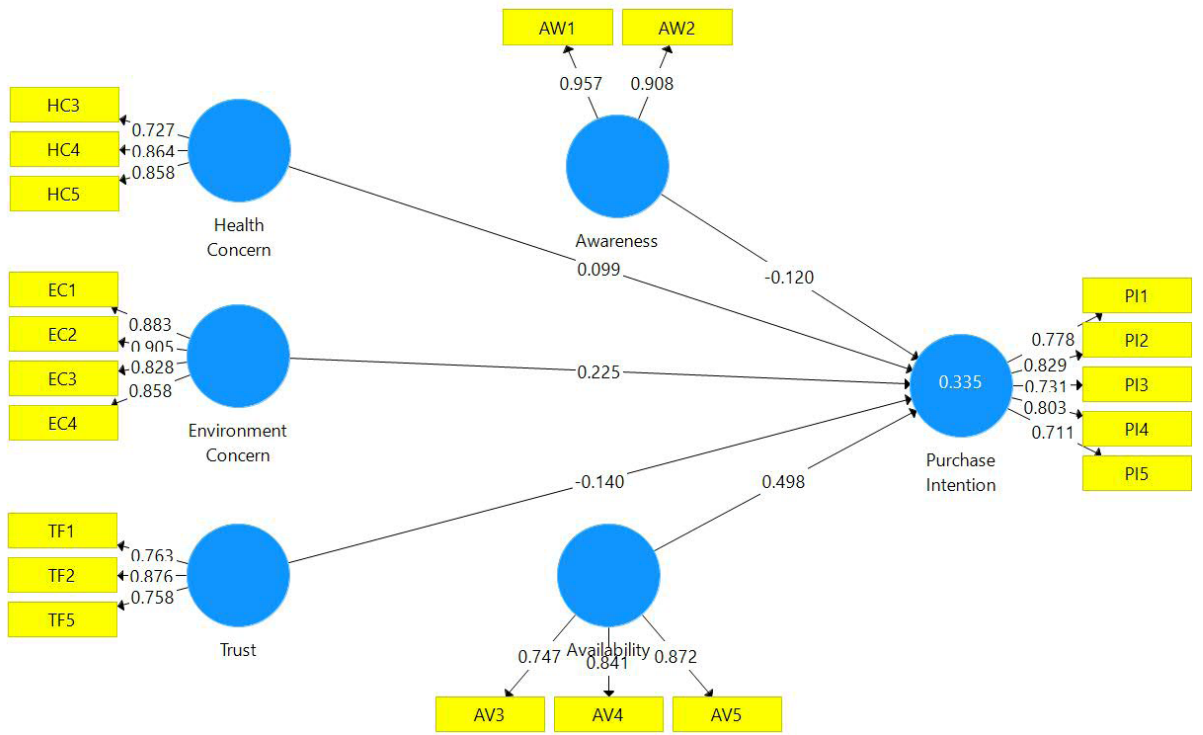

Figure 2 expresses the coefficient of determination value of the hypothesized model. The coefficient of determination of purchase intention (PI) is 0.335 or 33.5 percent. There is an influence of exogenous constructs - Health concern (HC), environment concern (EC), trust (TF), awareness (AW), and availability (AV) has an impact on organic foods purchase intention (PI) by 33.5 percent.

For evaluating discriminant validity, it is used by Fornell and Larcker Criterion (1981). The diagonal line is the square root of AVEs of the constructs, and it should be greater than the correlation value of rows and columns between objects (Henseler et al., 2015). It is explained in Table 2.

Table 2

Discriminant validity (Fornell \& Larcker criterion, 1981)

\begin{tabular}{|c|c|c|c|c|c|c|}
\hline Constructs & Availability & Awareness & $\begin{array}{c}\text { Environmental } \\
\text { Conscious }\end{array}$ & $\begin{array}{c}\text { Health } \\
\text { Consciousness }\end{array}$ & $\begin{array}{c}\text { Purchase } \\
\text { Intention }\end{array}$ & Trust \\
\hline Availability & $\mathbf{0 . 8 2 2}$ & & & & & \\
\hline Awareness & 0.299 & $\mathbf{0 . 9 3 3}$ & & & & \\
\hline $\begin{array}{c}\text { Environmental } \\
\text { Conscious }\end{array}$ & 0.39 & 0.41 & $\mathbf{0 . 8 6 9}$ & & & \\
\hline $\begin{array}{c}\text { Health } \\
\text { Consciousness }\end{array}$ & 0.176 & 0.21 & 0.574 & 0.819 & & \\
\hline $\begin{array}{c}\text { Purchase } \\
\text { Intention }\end{array}$ & 0.512 & 0.077 & 0.363 & 0.258 & 0.772 & \\
\hline Trust & 0.397 & 0.464 & 0.459 & 0.237 & 0.129 & $\mathbf{0 . 8 0 1}$ \\
\hline
\end{tabular}


As per Table 2, the average square root of variance shown in each diagonal line construct (bold) is higher than the correlation with the other constructs, thus proving that each construct is discriminated against and isolated from each other (Fornell \& Larcker, 1981). The research is sufficient for final assessment (Henseler et al., 2015).

Heterotrait-Monotrait (HTMT) establishes the ratio of average indicator correlations between constructs, separated by indicator correlations within the same construct (Henseler et al., 2015). The literature shows a 0.9 threshold (Hair et al., 2017; Henseler et al., 2015; Henseler et al., 2009).

Table 3

HTMT

\begin{tabular}{|c|c|c|c|c|c|c|}
\hline & Availability & Awareness & $\begin{array}{c}\text { Environmental } \\
\text { Conscious }\end{array}$ & $\begin{array}{c}\text { Health } \\
\text { Consciousness }\end{array}$ & $\begin{array}{l}\text { Purchase } \\
\text { Intention }\end{array}$ & Trust \\
\hline \multicolumn{7}{|l|}{ Availability } \\
\hline Awareness & 0.381 & & & & & \\
\hline $\begin{array}{c}\text { Environmental } \\
\text { Conscious }\end{array}$ & 0.456 & 0.467 & & & & \\
\hline $\begin{array}{c}\text { Health } \\
\text { Consciousness }\end{array}$ & 0.239 & 0.257 & 0.708 & & & \\
\hline $\begin{array}{l}\text { Purchase } \\
\text { Intention }\end{array}$ & 0.62 & 0.095 & 0.405 & 0.313 & & \\
\hline Trust & 0.496 & 0.58 & 0.574 & 0.319 & 0.141 & \\
\hline
\end{tabular}

Table 3 shows that all the values are below 0.9 demonstrate ample discriminating validity (Hair et al., 2017; Henseler et al., 2015; Henseler et al., 2009). All the constructions are below the threshold and therefore show the full validity of the discriminants.

\section{Structural model}

The structural model analyses the relationship between the health concern, environmental concern, trust, awareness, availability, and organic foods purchase intention constructs. Hypotheses have been checked with 5000 re-samples at a 5 percent level of significance using the bootstrapping technique. 
Figure 3

Structural model

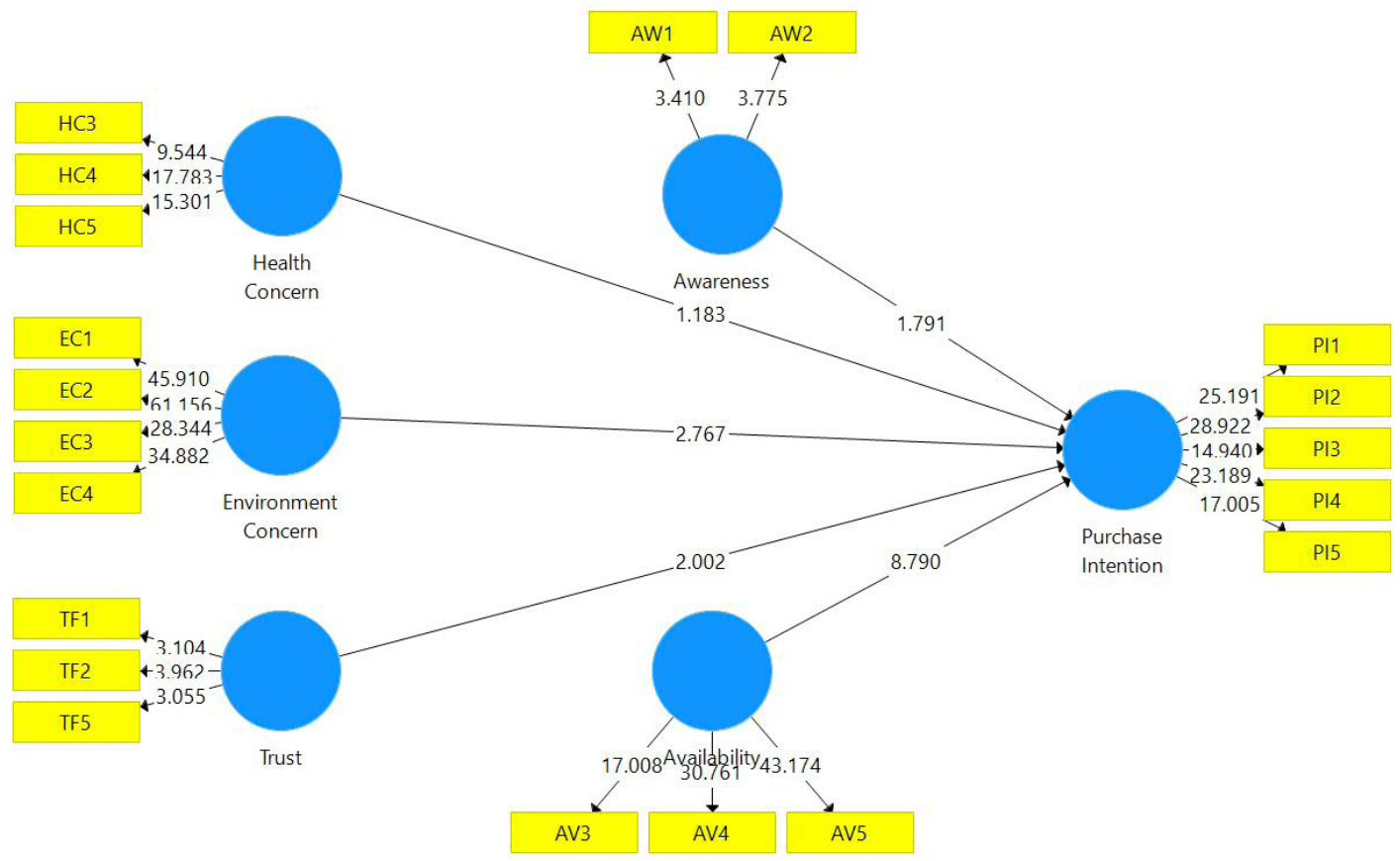

In figure3, the indicator items and path coefficients on the t-values are shown. Using the path coefficient $(\beta)$ and $t$-statistics values greater than 1.96, the relationships between exogenous and endogenous constructs were evaluated at the 5 percent significance level (Hair et al., 2012). The $R^{2}$ value in the structural model was used to test the proportion of the variance expressed by the exogenous constructs (Henseler et al., 2015). The research hypothesis is mentioned in Table 4.

Table 4

Hypothesis testing

\begin{tabular}{|l|c|c|c|c|}
\hline & Path & t-value & p-value & Decision \\
\hline H1: Health Concern -> Purchase Intention & 0.099 & 1.183 & 0.237 & $\begin{array}{c}\text { Not } \\
\text { Supported }\end{array}$ \\
\hline $\begin{array}{l}\text { H2: Environmental Concern -> Purchase } \\
\text { Intention }\end{array}$ & 0.225 & 2.767 & 0.006 & Supported \\
\hline H3: Trust -> Purchase Intention & -0.14 & 2.002 & 0.045 & Supported \\
\hline H4: Awareness -> Purchase Intention & -0.12 & 1.791 & 0.073 & $\begin{array}{c}\text { Not } \\
\text { supported }\end{array}$ \\
\hline H5: Availability -> Purchase Intention & 0.498 & 8.79 & 0.000 & Supported \\
\hline
\end{tabular}


Table 4 expresses the PLS-SEM measurement of the structural models showed that environmental concern $(\beta=0.225, t=2.767, p$-value $=0.006<0.050$, trust $(\beta=-0.14, t-v a l u e=2.002$, $\mathrm{p}$-value $=0.045<0.05)$, and availability $(\beta=0.498, \mathrm{t}$-value $=8.79, \mathrm{p}$-value $=0.000)$, have a positive impact on purchase intention, hence, giving significant assurance for the acceptance of $\mathrm{H} 2$, $\mathrm{H} 3$ and H5. But, the relationship between health concern and purchase intention $(\beta=.099$, $\mathrm{t}$-value $=1.183$, $\mathrm{p}$-value $=0.237)$, and awareness and purchase intention $(\beta=-0.12, \mathrm{t}$-value $=1.791$, $\mathrm{p}$-value $=0.073$ ) were not significant at 5 percent level of significance. So, H1 and H4 were not supported. In the Measurement model (Figure2), the $\mathrm{R}^{2}$ value of 0.335 shows that 33.5 percent of the overall variance in the endogenous variable, health concern, environmental concern, awareness, and availability, collectively predicts purchasing intention. The PLS-SEM results suggest that the tested model has moderate predictive ability and precision (Chin, 1998; Hair et al., 2011; Henseler et al., 2015).

\section{Conclusion}

The study's purpose was to examine the consumer purchase intention towards organic foods. This research confirmed that environmental concern, trust, and availability influence consumer purchase intention towards organic foods of the five proposed hypotheses.

It was found Environmental concern influence purchase intention towards organic foods. The finding is consistent with Bhatta et al. (2009) and Numraktrakul et al. (2011) that consumers showed more concern about organic food purchase environmental issues. Customers are favoring those products not to harm the environment. The research confirmed that trust is an important factor for purchasing organic food purchase intention. This confirmation aligns with Rizwan et al. (2013) that organic trust is the key to purchasing organic goods. The availability of organic foods also influences purchase intention. This finding is also consistent with Zhen and Mansori (2012), Davies et al. (1995), and Kaufmannu et al. (2012) that it helps them to behave socially. No availability of organic foods is a constraint for purchase (Sharma et al., 2016).

Health is a major concern, but the customer has given little importance to purchase organic foods. So, the findings are also different of Durham and Andrade (2005); Krystallis, and Chryssochoidis (2005); Padel, and Foster (2005); Suh et al. (2012); Yiridoe et al. (2005).

Customer is aware of organic foods, but they are not interested in purchasing organic foods. So, the result is in contrast with Chryssochoidis (2000), Padel and Foster (2005), Stobbelaar et al. (2007).

Organic consumer markets are niche markets, and companies should make it from class to mass markets. People are aware of the environment. People, therefore, need to realize their wellbeing. Marketing communication plays a persuasive responsibility in facilitating that organic food is the secret to their wellbeing. Urbanization is expanding, and there is an increase in concern for organic food. Since organic foods are being sold through supermarkets or special outlets, marketers need to sell them online. 
The analysis means that the researcher contributes methodologically. In this study, PLS-SEM, an advanced modeling technique was used. The researcher used two-stage analysis approaches for the model's psychometric and econometric properties. The measurement model was evaluated psychometrically, and the structural model was tested econometrically.

\section{References}

Adhikari, S. (2014). Organic farming booming in Nepal. http://www.newbusinessage.com/ Focus $\% 20$ News $/ 2430$

Ajzen, I. \& Fishbein, M. (1975). Belief, attitude, decision and behavior: An introduction to theory and research. http://www.uky.edu/ drlane/capstone/health/reson.html.

Ajzen, I. (1991). The theory of planned behaviour. Organizational Behavior and the Human Decision Process, 50, 179-211.

Ajzen, I., \& Fishbein, M. (1980). Understanding attitudes and predicting social behavior. Englewood Cliffs, NJ: Prentice-Hall.

Ali, F., Rasoolimanesh, S.M., Sarstedt, M., Ringle, C.M., \& Ryu, K. (2018). An assessment of the use of partial least squares structural equation modeling (PLS-SEM) in hospitality research. International Journal of Contemporary Hospitality Management, 30(1), 514-538. https://doi.org/10.1108/IJCHM10-2016-0568

Aryal, K.P., Chaudhary, P., Pandit, S., \& Sharma, G. (2009). Consumers' willingness to pay for organic products: A case from Kathmandu Valley. The Journal of Agriculture and Environment, 10, 12-22.

Ashforth, B.E., \& Mael, F.A. (1989). Social identity theory and organization. The Academy of Management Review, 14(1), 20-39. Doi: 10.5465/ AMR.1989.4278999

Azizan, S.A.M., \& Suki, N.M. (2014). The potential for greener consumption: Some insights from Malaysia. Mediterranean Journal of Social Sciences, 5(6), 11-21

Bahr, M., Botschen, M., Laberentz, H., Naspetti, S., Thelen, E., \& Zanoli, R. (2004). The European consumer and organic food. School of Management and Business, University of Wales Aberystwyth, Aberystwyth.

Bharathi, B., Ananthnag, K., \& Nagarana, N. (2014). Buying behaviour of urban residents towards organically produced food products. International Journal of Research in Applied, Natural and Social Sciences, 2(2), 33-38.

Bhatta, G.D., Doppler, W., \& KC, K.B. (2009). Potentials of organic agriculture in Nepal. The Journal of Agriculture and Environment, 10, 1-11.

Briz, T., \& Ward, R.W. (2009). Consumer awareness of organic products in Spain. An application of multinomial logit models. Food Policy, 34, 295-304.

Brown, J.D., \& Wahlers, R.G. (1998). The environmentally concerned consumer: An exploratory study. Journal of Marketing Theory and Practice, 6(2), 39-47 
Brunel, O. (2003). Food risk adjustment strategies (Les strate'gies d'ajustement au risque alimentaire). Proceedings of the Congress of the French Marketing Association (Actes du Congre's de l'Association Francaise de Marketing), Gammarth, Tunisia, 19.

Cavana, R., Delahaye, B.L., \& Sekaran, U. (2000). Applied business research: Qualitative and quantitative methods. Milton Queensland: John Wiley \& Sons Australia Ltd.

Chen, M.F. (2007). Consumer attitudes and purchase decisions in relation to organic foods in Taiwan: Moderating effects of food-related personality traits. Food Quality and Preference, 18(7), 1008-1021.

Chen, Y. (2010). The drivers of organic brand equity: Organic brand image, organic satisfaction, and organic trust. Journal of Business Ethics, 93(1), 81-92.

Chen, Y., \& Chang, C. (2012). Enhance green purchase intention: The roles of green perceived value, green perceived risk, and green trust. Management Decision, 50(3), 502-520. Doi: $10.1108 / 00251741211216250$

Chin, W.W. (1998). Issues and opinion on structural equation modeling. MIS Quarterly, 22(1), 7-16.

Chryssochoidis, G. (2000). Repercussions of consumer confusion for late introduced differentiated products. European Journal of Marketing, 34, 705- 722.

Dahama, A.K. (1997). Organic farming for sustainable agriculture. New Delhi: Ashila Offset Printers.

Davies, A., Titterington, A.J., \& Cochrane, C. (1995). Who buys organic food? A profile of the purchasers of organic food in Northern Ireland. British Food Journal, 97(10), 17-23.

Dhungana, S. (2014) Organic vegetables stores doing brisk business. http://myrepublica.com/ portal/index.php/\%5C\%5

Dillman, D. (2000). Mail and internet surveys: The tailored design method (2nd ed.). New York, NY: Wiley Corporation.

Durham, C.A., \& Andrade, D. (2005). Health vs. environmental motivation in organic preferences and purchases. American Agricultural Economics Association Annual Meeting, Providence, Rhode Island.

Fornell, C., \& Larcker, D.F. (1981). Evaluating structural equation models with unobservable variables and measurement error. Journal of Marketing Research, 18(1), 39-50

Ghauri, P., \& Gronhaug, K. (2005). Research methods in business studies: A practical guide ( $3^{\text {rd }}$ Ed.). London: Prentice-Hall.

Gil, J.M., \& Soler, F. (2006). Knowledge and willingness to pay for organic food in Spain: Evidence from experimental auctions. Food Economics, 3, 109-124.

Gupta, S., \& Ogden, D.T. (2009). To buy or not to buy? A social dilemma perspective on green buying. Journal of Consumer Marketing, 26(6), 376-391. 
Gurviez, P., \& Korchia, M. (2012). Proposal for a multidimensional measurement scale for brand confidence (Proposition d'une échelle de mesure multidimensionnelle de la confiance dans la marque). Marketing Research and Applications (Rechercheet Applications en Marketing), 17(3), 41-61.

Hair, J.F., Hult, G.T.M., Ringle, C., \& Sarstedt, M. (2013). A primer on partial least squares structural equation modelling (PLS-SEM). Los Angeles: Sage Publications.

Hair, J.F., Hult, G.T.M., Ringle, C., \& Sarstedt, M. (2017). A primer on partial least squares structural equation modeling (PLS-SEM) (2nd ed.). Thousand Oaks, California: Sage Publications Limited, Inc.

Hair, J.F., Matthew, H., \& Christian, N. (2020). Assessing measurement model quality in PLS-SEM using confirmatory composite analysis. Journal of Business Research, 109, 101-110. https://mattchoward.files.wordpress.com/2020/03/hair_howard_nitzl jbr_2020.pdf

Hair, J.F., Ringle, C.M., \& Sarstedt, M. (2011). PLS-SEM: Indeed a silver bullet. Journal of Marketing Theory and Practice, 19(2), 139-152. https://doi.org/10.2753/MTP1069$\underline{6679190202}$

Hair, J.F., Sarstedt, M., Ringle, C.M., \& Mena, J.A. (2012). An assessment of the use of partial least squares structural equation modeling in marketing research. Journal of the Academy of Marketing Science, 40(3), 414-433.

Hamzaoui, L., \& Zahaf, M. (2008). Profiling organic food consumers: Motivations, trust orientations and purchasing behavior. Journal of International Business and Economics, 8, 25-39

Henry, G.T. (1990). Practical sampling. London: Sage Publications.

Henseler, J., Ringle, C.M., \& Sarstedt, M. (2015). A new criterion for assessing discriminant validity in variance-based structural equation modeling. Journal of the Academy of Marketing Science, 43(1), 115-135. https://doi.org/10.1007/s11747-014-0403-8

Henseler, J., Ringle, C.M., \& Sinkovics, R.R. (2009). The use of partial least squares path modeling in international marketing. Advances in International Marketing, 20(1), 277-319. https://doi.org/10.1108/S1474-7979(2009)0000020014

Herek, G. (1995). Developing a theoretical framework and rationale for a research proposal. In W. Pequegnat and E. Stover (Eds.), How to write a successful research grant application: A guide for social and behavioral scientists (pp. 85-91). Norwell, MA: Kluwer.

Huang, W.K.D., \& Teng, Y. (2013). Environmental concern, attitudes and decisions towards patronage of organic restaurants. Life Science Journal, 10(4), 2329-2340

Kaufmannu, H.R., Panni, M.F.A.K., \& Orphanidou, Y. (2012). Factors affecting consumers' green purchasing behavior: An integrated conceptual framework. Anfiteatro Economic Journal, 14(31), 50-69 
Kayaman, R., \& Arasli, H. (2007). Customer-based brand equity: Evidence from the hotel industry. Managing Service Quality, 17(1),92-109

Kim, Y., \& Han, H. (2010). Decision to pay conventional-hotel prices at a organic hotel: A modification of the theory of planned behavior. Journal of Sustainable Tourism, 18(8), 997-1014.

Kline, R.B. (2011). Principles and practice of structural equation modeling (3rd ed.). New York: The Guildford Press.

Kobayashi, F. (2011). Japanese high school students' television viewing and fast food consumption. Nutrition \& Food Science, 41(4), 242-248

Krystallis, A., \& Chryssochoidis, G.M. (2005). Consumers' willingness to pay for organic food: Factors that affect it and variation per organic product type. British Food Journal, 107(5), 320-343

Lea, E., \& Worsley, T. (2005). Australians' organic food beliefs, demographics and values. British Food Journal, 107(11), 855-869.

Magistris, T., \& Gracia, A. (2008). The decision to buy organic food products in Southern Italy. British Food Journal, 110(9), 929-947.

Mahato, S., \& Kadel, R.P. (2015). Consumer perception and purchase intention towards organic food products in Nepal. Advances in Economics and Business Management (AEBM), 2(11), 1052-1054.

Mainieri, T., Barnett, E., Valdero, T., Unipan, J., \& Oskamp, S. (1997). Green buying: The influence of environmental concern on consumer behavior. Journal of Social Psychology, 137(2), 189-204

Malhotra, N.K., \& Birks, D.F. (2006). Marketing research: An applied approach (2nd European ed.). Harlow: Financial Times, Prentice-Hall.

Mostafa, M.M. (2007). Gender differences in Egyptian consumers' Organic purchase behaviour: the effects of environmental knowledge, concern and attitude. International Journal of Consumer Studies, 31(3), 220-9.

Numraktrakul, P., Ngarmyarn, A., \& Panichpathom, S. (2011). Factors affecting green housing purchase. www.wbiconpro.com/508.Atcharawan.pdf

Ottman, J. (1992). Sometimes consumers will pay more to go green. Journal of International Consumer Marketing, 16, 12-120.

Padel, S., \& Foster, C. (2005). Exploring the gap between attitudes and behavior understanding why consumers buy or do not buy organic food. British Food Journal, 107(8), 606-625.

Peter, J.P., \& Olson, J.C. (2002). Consumer behaviour and marketing strategy (6th ed.). USA: McGraw-Hill Companies. 
Rizwan, M., Hassan, M., \& Javeed, U. (2013). Future of green products in Pakistan: An empirical study about green purchase intentions. Asian Journal of Empirical Research, $3(4), 87-100$

Roitner-Schobesberger, B., Darnhofer, I., Somsook, S., \& Vogl, C. (2008). Consumer perceptions of organic food in Bangkok, Thailand. Food Policy, 33, 112-121.

Salzman, J. (1991). Organic labels for consumers. OECD Observers, 169, 28-30

Sangkumchalianga, P. \& Huang W. (2012). Consumers' perceptions and attitudes of organic food products in Northern Thailand. International Food and Agribusiness Management Review, 15(1), 1-16.

Shamsollani, A., Chong, C.W., \& Nahid, N. (2013). Factors influencing on purchasing behaviour of organic foods. Human and Social Science Research,1(2), 93-104

Sharma, P., Uprety, P., \& Phuyal, R.K. (2016). An analysis of consumer's purchase behavior on organic foods in Kathmandu Valley. Advances in Economics and Business Management (AEBM), 3(5), 514-526

Siriex, L., Pontier, S., \& Schaer, B. (2004). Orientations of trust and choice of distribution channel: the case of organic products (Orientations de la confiance et choix du circuit de distribution: le cas des produits biologiques). Proceedings of the $10^{\text {th }}$ FMA International Congress., St. Malo France.

Stobbelaar, D.J., Casimir, G., Borghuis, J., Marks, I., Meijer, L., \& Zebeda, S. (2007). Adolescents' attitudes towards organic food: A survey of 15- to 16-year old school children. International Journal of Consumer Studies, 31(4), 349-356.

Suh, B.W., Eves, A., \& Lumbers, M. (2012). Consumer's attitudes and understanding of organic food: The case of South Korea. Journal of Foodservice Business Research, 15(1), 49-63.

Tajfel, H. (1981). Human groups and social categories: Studies in social psychology. Cambridge: Cambridge University Press.

Tajfel, H. (1982). Social psychology of intergroup relations. Annual Review of Psychology, 33, 1-39

Thapa, G. (2019). Consumers' perception towards green products in Nepal. NCC Journal, 4(1), 47-57. https://doi.org/10.3126/nccj.v4i-24736

Trochim, W.M.K. (2006). Research methods knowledge base. http://www.socialresearchmethods. net $/ \mathrm{kb} /$

Tsakiridou, E., Boutsouki, C., Zotos, Y., \& Mattas, K. (2008). Attitudes and behaviour towards organic products: An exploratory study. International Journal of Retail \& Distribution Management, 36(2), 158-175.

Vermeir, I., \& Verbeke, W. (2004). Sustainable food consumption: Exploring the consumer attitude-behavior gap. Working papers on Faculty of Economics and Business Administration, Ghent University. 
Yiridoe, E.K., Bonti-Ankomah, S., \& Martin, R.C. (2005). Comparison of consumers perceptions and preferences toward organic versus conventionally produced foods: A review and update of the literature. Renewable Agriculture and Food System, 20, 193-205.

Zelezny, L.C., \& Schultz, P.W. (Eds.). (2000). Promoting environmentalism. Journal of Social Issues, 56(3), 365-371

Zhen, J.S., \& Mansori, S. (2012). Young female motivations for purchase of organic food in Malaysia. International Journal of Contemporary Business Studies, 3(5),61-72 